\title{
Analog Rice Development as Alternative Food Made of Raw Composite Flour Enriched Protein Canavalia ensiformis
}

\author{
Isti Pudjihastuti ${ }^{1}{ }^{*}$, Siswo Sumardiono ${ }^{2}$, Heny Kusumayanti ${ }^{3}$

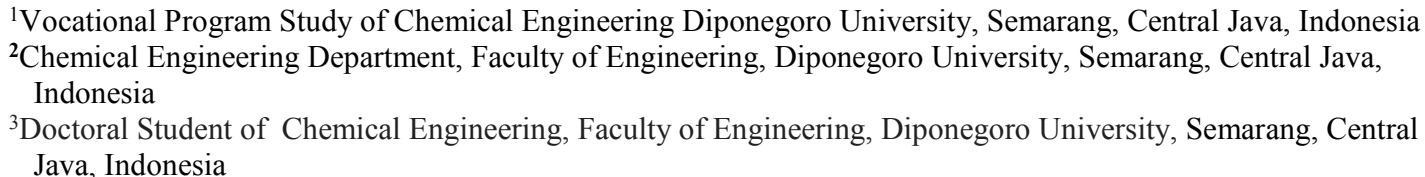

\begin{abstract}
Food is an important factor in human life. Indonesia's main food need is rice. Domestic rice demand continues to increase along with population growth. One of the businesses that can increase the availability of food, especially rice, is to utilize the existing agricultural products even though they have not been utilized economically and intensified the excavation of new food sources. Analog rice is a form of food diversification by utilizing local carbohydrate sources. In this study analog rice made from composite flour mixture of cassava flour, Dioscorea esculenta $L$, corn enriched with protein Canavalia ensiformis. The purpose of this research is to develop the method of production of analog rice and to test the physicochemical properties including water content, water, protein, and amylose so that it can be applied as food substitute for rice in realizing Indonesia food security program. The largest protein content of $9.156 \%$, the highest water content of $12.431 \%$, water absorption $187 \%$. The amylose content of analog rice amounted to $19.677 \%$ included in the low-octane rice.
\end{abstract}

Keywords: analog rice; composite ; alternative food ; protein

\section{Introduction}

Rice is a basic necessity of Indonesia and continues to increase every year. Dependence on rice has become a major problem with the increasing population of Indonesia because it is not offset by increased rice production. The increase in population is in line with the increase of national rice consumption. This prompted the Government of Indonesia to import 1.92 million tons of rice by 2014[1]. The high import of rice indicates that domestic production has not met the food needs of Indonesians. This factor encourages the diversification of non-rice food. Diversification of staple food consumption is one effort to maintain food security. The diversification of staple food consumption is not intended to replace the total rice but to change the food consumption pattern of the people, so that the society does not depend on one type of staple food[2].

Non-rice-based food diversification from other sources of carbohydrates such as corn, cassava, sorghum, sago and other tubers is the focus of the government with considerable potential[3] but the potential for non-rice food has not been optimally utilized. Cassava is one of the alternative food potential that can be developed as a source of carbohydrates because cassava production each year has increased. Potential of cassava development is very big considering Indonesia is the third largest cassava producer after Brazil and Thailand[4]. In addition, corn (Zea mays L) also has great potential as a source of food that can be developed. Indonesia's corn production also continues to increase significantly from 6.73 million tons to 17.64 million tons in the period of 1990-2011 or at a rate of $5.34 \%$ per year.

Another carbohydrate source that can be developed as an alternative food is Dioscorea esculenta. The superiority of the discorea group is to contain bioactive compounds or functional compounds, in addition to the components that serve as food ingredients[5]. National production of large Dioscorea esculenta is about 2 tons per Ha. Based on its nutritional content, Dioscorea esculenta has a high carbohydrate content up to $90 \%$. Dioscorea esculenta flour has an advantage, as it is cheap, easy to obtain and can be used as composite flour with other types of flour with some improvement on its physicochemical properties[6]. Composite Flour: Modified Starch, Colocasia Esculenta,

* Corresponding author: istipudjihastuti@gmail.com 
Canna Edulis Ker High Protein can make analog rice with low amylose [7].

In addition to carbohydrates, there are other components needed by the body one of them is protein. Protein sources can come from animal proteins such as marine fish and vegetable proteins such as nuts. Types of nuts that have high protein content and can be developed into alternative food one of them Canavalia ensiformis L. Canavalia ensiformis $L$ has a protein content that is not less high than the green beans reaching 23-27\%[8]. In 2012 Canavalia ensiformis production reaches 300 tons per year, so Canavalia ensiformis can be used as an alternative source of protein. This is the factor that encourages the diversification of non-rice food. One of the diversification of non-rice food currently being developed is the manufacture of analog rice.

In this research, analog rice made from composite flour (cassava, Dioscorea esculenta and maize) is enriched with protein of Canavalia ensiformis. The economic value of this analog rice in terms of ingredients such as cassava flour, Dioscorea esculenta and corn is very easy to obtain but its utilization is less than maximum, besides not many Canavalia ensiformis utilized[9]. Therefore, these materials need to be cultivated for planting, in addition to reforestation and their harvests can also be used to realize low-carbon development in the development process.

The concentration of $\mathrm{CO}_{2}$ in the atmosphere is regulated from the soil. Whereas soil $\mathrm{CO}_{2}$ flux or soil respiration is an important indicator in an ecosystem, the amount of root respiration and decomposition of heterotrophic soil organic matter [10][11]. To find out the soil organic carbon content, information on money is needed to function for sustainable land management, but in making maps like iin, it costs a lot of money and the time frame is not short [12]. There needs to be planning for the community where to overcome the lack of energy supply and its effects can make an increase in climate change. Developing the concept of low carbon technology, promoting a low carbon concept is an efficient way [13]. There needs to be considerations which are the path of transition, fundamental institutions, individuals and the existence of social change which is needed to accompany changes in the economy and technology because of the overall embedded energy in the pattern of development [14].

This study aims to create and test the physicochemical properties of analog rice made from composite starch protein-enriched protein composites which includes moisture content. Power of fiber, texture and protein.

Water can disperse various polar compounds present in the foodstuff, thereby affecting the increase in the water content of the analog rice. Safe water content for rice storage that is, $14 \% \mathrm{bb}[15]$. With moisture content, $14 \% \mathrm{bb}$ will prevent the growth of mold that often live on cereals / grains. The production of analog rice that has been patented granulation method begins with the mixing stage of flour, water and hydrocolloids as a binder[16]. The mixing process is carried out at a temperature of $30-80^{\circ} \mathrm{C}$, so that some of the dough has undergone gelatinization.

\section{Materials and Methods}

The materials used in this research are composite flour (cassava, Dioscorea esculenta and corn) and Canavalia ensiformis flour, aquadest and analysis materials. This research begins with the manufacture of Cassava flour, Dioscorea esculenta, maize and Canavalia ensiformis. Analog rice made analyzed its characteristics. Analog rice formulation in accordance with Table 1.

The implementation of analog rice production begins with weighing the shoulder material according to the prescribed treatment. Furthermore, the raw materials that have been weighed mixed, plus aquadest of 1000 $\mathrm{mL}$ and inserted extruder machine. Grains of rice that comes out of the next machine in the wind so that the analog rice dry. Next step is measurement of water content, water absorption, protein content and amylose.
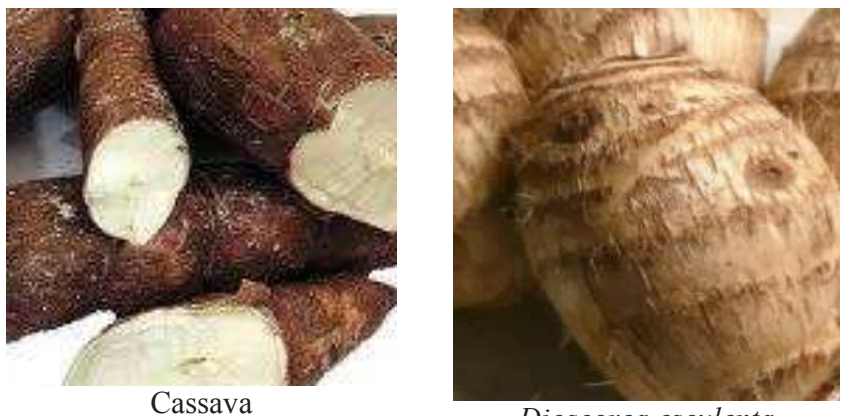

Dioscorea esculenta

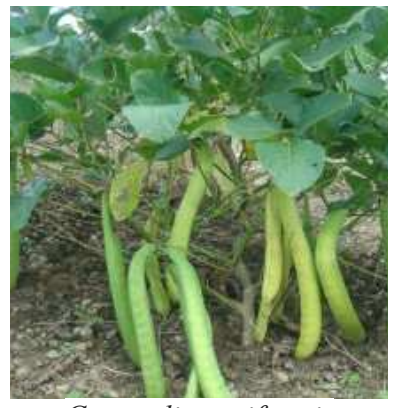

Canavalia ensiformis

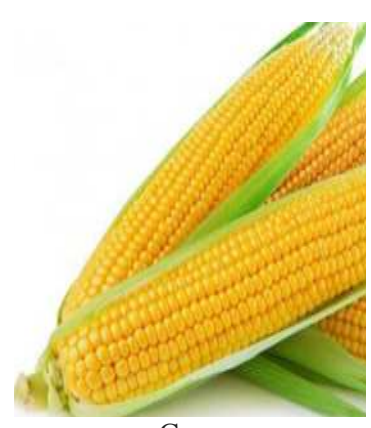

Corn

Fig. 1. Materials this research 
Table 1. Comparison of the ingredients for every 1000 gr of sample material

\begin{tabular}{|c|c|c|c|c|}
\hline No & $\begin{array}{c}\text { Cassava } \\
(\%)\end{array}$ & $\begin{array}{c}\text { Dioscorea } \\
\text { esculenta } \\
(\%)\end{array}$ & $\begin{array}{c}\text { Canavalia } \\
\text { ensiformis } \\
(\%)\end{array}$ & $\begin{array}{c}\text { Corn } \\
(\%)\end{array}$ \\
\hline 1 & 55 & 15 & 15 & 15 \\
\hline 2 & 50 & 20 & 15 & 15 \\
\hline 3 & 50 & 15 & 15 & 20 \\
\hline 4 & 50 & 15 & 20 & 15 \\
\hline
\end{tabular}

\section{Results and Discussion}

The water content obtained in some analog rice manufacturing treatments ranged from $8.447-12.431 \%$.
Figure 2 is a graph of moisture content obtained from each treatment on analog rice production of the test results.

The water content obtained is near the maximum water content of milled rice that is $14 \%$ and has met the required water level by SNI 01-6128-2008, which is a maximum of $14 \%$. This figure is a safe water content for rice storage that is $<14 \% \mathrm{bb}$. With a water content of $<14 \%$ bb will prevent mold growth that often lives on cereals /grains[15]. From the results of the analysis shows that the composition of the mixture of raw materials does not affect the water content of analog rice. The greater the value of water absorption, the more water needed to cook the rice. Based on the research, the average absorption rate of rice water ranged from 173-187 can be seen in Figure 3.

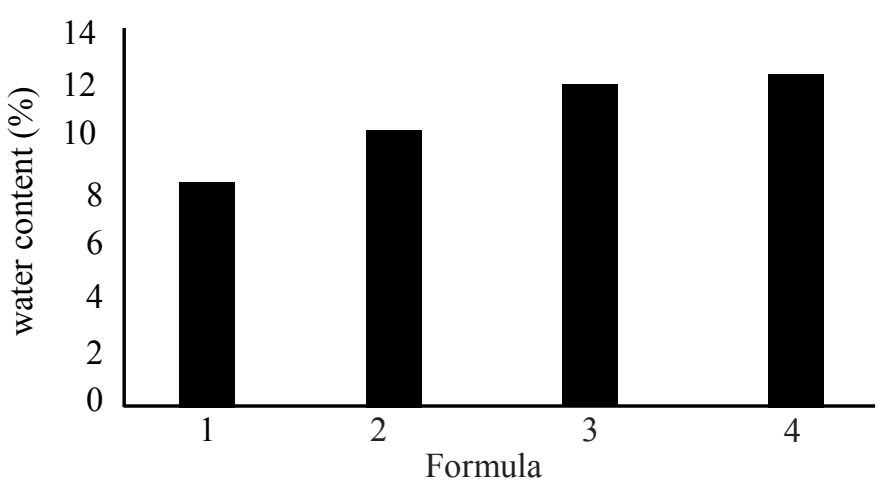

Fig. 2. Graph of water content of each treatment

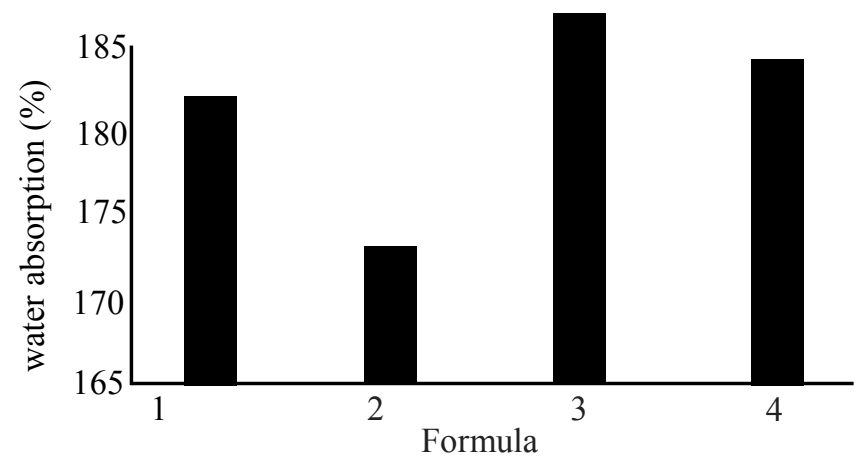

Fig. 3. Graph of each water absorption Treatment

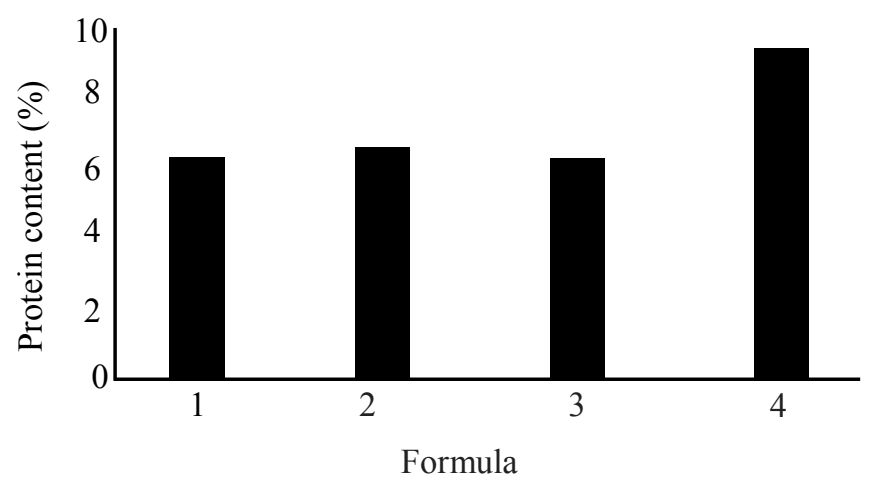

Fig. 4. Graph of each protein content Treatment 
According to composite test the composite flour mixture does not affect the absorption of rice water of analog. The average water absorption from rice in Indonesia is 2.5 times. The greater the level of water absorption, the greater the water needed to cook the rice. Analog rice has a water absorption rate that is smaller than ordinary rice. The protein content obtained in some analog rice manufacturing treatments ranged from 6.157 to $9.156 \%$. Fig. 4 is a graph of the protein content obtained from each treatment on the manufacture of analog rice from the measurement results.

From the analysis of protein rice content of analogs at various treatments, the composite starch composition affects the amount of protein content. Composition 4 with raw materials $50 \%$ cassava, 155 Dioscorea esculenta, 15\% corn and 20\% Canavalia ensiformis showed the highest protein content of $9.156 \%$.

Amylose content is one of the chemical properties that determine the physical properties of rice. Based on the analysis, analog rice has amylose levels $13.126-19.677 \%$. Based on these results, analog rice is included in the low-octane rice when cooked to produce sticky rice, shiny, not fluffy and remain clot after cold. But amylose levels can not determine the level of favorite rice because people's tastes of delicious rice different[15].

\section{Conclusion}

From the research results obtained rice analogous to the largest protein content of $9.156 \%$, the highest water content of $12.431 \%$, water absorption $187 \%$ and amylose content $19.677 \%$ The amylose content of analog rice amounted to $19.677 \%$ included in lowtempered rice.

\section{Acknowledge}

Thank you to the University of Diponegoro who has funded this research with the source of PNBP funds in the RPP scheme.

\section{Reference}

1. Badan Statistik Indonesia, Pertumbuhan Penduduk Indonesia, Biro Pusat Statistik, Jakarta, (2014).

2. M. Ariani, Diversifikasi konsumsi pangan pokok mendukung swasembada beras, Pros. Pekan Serealia Nas., pp. 65-73, (2010)

3. S. K. Dewi, Pembuatan Produk Nasi Singkong Instan Berbasis Fermented Cassava Flour Sebagai Bahan Pangan Pokok Alternatif, (Bogor Agricultural University, 2008).

4. Badan Ketahanan Pangan Kementerian Pertanian,
Roadmap diversifikasi pangan 2011-2015," 2012.

5. T. E. Harijono, W. B. Sunarharum, and I. S. Rakhmita, Karakteristik Kimia Ekstrak Polisakarida Larut Air dari Umbi Gembili (Dioscorea Esculenta) yang Ditunaskan, (Universitas Brawijaya, 2010).

6. N. Richana and T. C. Sunarti, Karakterisasi sifat fisikokimia tepung umbi dan tepung pati dari umbi ganyong, suweg, ubi kelapa, dan gembili, $J$. pascapanen, 1, 1:29-37 (2004).

7. I. Pudjihastuti, S. Sumardiono, E. Supriyo, and H. Kusumayanti, Quality analog rice composite flour: Modified starch, Colocasia esculenta, Canna edulis Ker high protein, in AIP Conference Proceedings, 1977, 1:30017 (2018).

8. S. Handajani and W. Atmaka, Analisa sifat PhisisKhemis Beberapa Biji Kacang-Kacangan, kekerasan, Kualitas Tanak, Protein, dan Kandungan Mineralnya, (Universitas Sebelas Maret 1993).

9. S. Sumardiono, I. Pudjihastuti, N. A. Handayani, and H. Kusumayanti, Physicochemical Characteristics of Artificial Rice from Composite Flour: Modified Cassava Starch, Canavalia ensiformis and Dioscorea esculenta, in E3S Web of Conferences, 31, 6005 (2018).

10. J. W. Raich and W. H. Schlesinger, The global carbon dioxide flux in soil respiration and its relationship to vegetation and climate, Tellus $B, \mathbf{4 4}$, 2:81-99, (1992).

11. K. E. Savage and E. A. Davidson, Interannual variation of soil respiration in two New England forests, Glob. Biochem. Cycles, 15, 2:337-350, (2001).

12. E. Mason and Y. Sulaeman, Comparison Of Three Models For Predicting The Spatial Distribution Of Soil Organic Carbon In Boalemo Regency, Sulawesi, J. Ilmu Tanah dan Lingkung., 18, 1:4248, (2018).

13. L. Yu, Low carbon eco-city: New approach for Chinese urbanisation, Habitat Int., 44, pp. 102-110, (2014).

14. J.-C. Hourcade and R. Crassous, Low-carbon societies: a challenging transition for an attractive future, Clim. Policy, 8, 6:607-612, (2008).

15. S. S. Widara and S. Budijanto, Study of Rice Analogue Production from Various Carbohydrate Sources Using Hot Extrusion Technology, (Fakultas Teknologi Pertanian. Institusi Pertanian Bogor, 2012).

16. H. Kurachi, Process for producing artificial rice, (United States Patent 1995). 